\title{
Incentiver og deltagelse i en medisinsk spørreundersøkelse
}

\begin{abstract}
BAKGRUNN Spørreundersøkelser er viktige for å kartlegge befolkningens helse- og sykdomsatferd, men de siste årene er det observert fallende deltagelse. Vi har undersøkt om incentiver kan gi økt deltagelse i slike undersøkelser.
\end{abstract}

MATERIALE OG METODE Vi sendte et spørreskjema om risikofaktorer for kolorektal kreft (høyde, vekt, røyking, selvrapporterte diagnoser, familieanamnese) til ikke-screenede deltagere i en randomisert koloskopiscreeningsstudie for kolorektal kreft. De som mottok skjemaet var deltagere som var invitert, men ikke hadde møtt til koloskopiundersøkelse (screeninginviterte) og personer som ikke ble tilbudt koloskopi (kontrollgruppen). De ble randomisert til tre grupper: ingen økonomiske incentiver, skrapelodd vedlagt skjemaet eller deltagelse i utlodning av nettbrett ved svar på spørreskjemaet. Vi gjennomførte telefonpurring for alle incentivgruppene og før nettbrettrekningen.

RESULTATER 3705 av 6795 (54,5\%) besvarte spørreskjemaet - 43,5\% av de screeninginviterte og 65,6\% i kontrollgruppen ( $p<0,001)$. Svarandelen var ikke påvirket av incentiver, verken blant screeninginviterte (42,4\% i ikke-premiegruppen, $45,5 \%$ i skrapeloddgruppen og 42,6\% i utlodningsgruppen; $p=0,24)$ eller i kontrollgruppen $165,6 \%$ i ikke-premiegruppen, $66,4 \%$ i skrapeloddgruppen og $64,7 \%$ i utlodningsgruppen; $p=0,69)$. Før purring svarte $39,2 \%$. Ytterligere $15,3 \%$ svarte etter telefonpurring $(14,1 \%$ av de screeninginviterte og $16,5 \%$ i kontrollgruppen; $p<0,0011$.

FORTOLKNING Incentiver ga ikke økt deltagelse i denne medisinske spørreskjemaundersøkelsen. Bruk av telefonpurring og telefonintervju økte den, men hvorvidt dette er mer effektivt enn andre metoder, må studeres videre.

Høy deltagelse i spørreundersøkelser, og dermed mer representative data om helse, sykdom og risiko, har bidratt til høy kvalitet på epidemiologisk forskning i Norge $(1,2)$ og i de andre skandinaviske land (3-5). Dette har gitt oss en unik mulighet til å forstå befolkningens risiko for sykdom og til å planlegge forebyggende tiltak rettet mot hele befolkningen eller undergrupper av pasienter.

I de senere år har imidlertid andelen som deltar i slike studier falt. Helseundersøkelsen i Nord-Trøndelag (HUNT) startet med et spørreskjema i 1984-86 som ble besvart av $89 \%$ av de forespurte. Deltagelsen falt til $69,5 \%$ i $1995-97$ og til $54 \%$ i 2006-08 (6). Fallende oppslutning er også sett i andre norske helseundersøkelser, som de ulike utgavene av Tromsø-undersøkelsen (7) og i mor-og-barn-undersøkelsen (8). Med fallende vilje til å delta i spørreundersøkelser de siste tiårene $(1,2,9)$ er det viktig å kartlegge mulighetene for å øke oppslutningen.

Utover design og innhold i spørreskjema og følgebrev/konvolutt er det forsket særlig på tre ulike virkemidler for å øke deltagelsen: bruk av ulike måter å besvare undersøkelser på, ulike former for påminnelser (purring) og incentiver (10-20). Et incentiv er noe som motiverer eller stimulerer til en bestemt handling, og kan inndeles i ubetingede og betingede incentiver, der sistnevnte forutsetter deltagelse.
Intuitivt burde incentiver virke motiverende til deltagelse for dem som ellers ville latt være, men effekten i medisinske spørreundersøkelser er usikker. I flere studier har man funnet at økonomiske incentiver som gaver eller gevinster i form av utlodning, gavekort eller pengebeløp har effekt, men de fleste studiene er små, og resultatene spriker (10,20-22). Sammenligning av ulike incentiver er særlig vanskelig fordi man har brukt forskjellige incentiver i ulike studier og studert effekten i ulike pasientgrupper (10). Det finnes få publiserte randomiserte studier fra Norge der man har sammenlignet effekten av forskjellige typer incentiver på deltagelsen i medisinske og helsefaglige studier, og det er sprikende konklusjoner i de studiene som finnes $(21,22)$.

Formålet med denne studien var å undersøke hvorvidt bruk av incentiver ga økt deltagelse i en befolkningsbasert helseundersøkelse, og eventuelt hvilket incentiv som medførte høyest svarprosent.

\section{Materiale og metode}

Spørreskjemaundersøkelsen ble gjennomført innenfor den norske delen av NordICC-studien (Nordic-European Initiative on Colorectal Cancer) (23), som inkluderte 26417 tilfeldig utvalgte kvinner og menn i alderen 55-64 år bosatt i Aust- eller Vest-Agder. Disse ble randomisert 1:2 til screeninggrup-

\author{
Dagrun Kyte Gjøstein \\ d.k.gjostein@medisin.uio.no \\ Avdeling for helseledelse og helseøkonomi \\ Universitetet i Oslo \\ Anders Huitfeldt \\ Harvard TH Chan School of Public Health \\ og \\ Oslo universitetssykehus \\ og \\ Stanford University School of Medicine
}

\section{Magnus Løberg}

Avdeling for helseledelse og helseøkonomi Universitetet i Oslo

og

Avdeling for transplantasjonsmedisin

og K.G. Jebsen senter for kolorektal cancer Oslo universitetssykehus

\section{Hans-Olov Adami}

Avdeling for helseledelse og helseøkonomi Universitetet i Oslo

og

Avdeling for transplantasjonsmedisin og K.G. Jebsen senter for kolorektal cancer Oslo universitetssykehus

og

Karolinska institutet

og

Harvard TH Chan School of Public Health

\section{Kjetil Garborg}

Avdeling for transplantasjonsmedisin

Oslo universitetssykehus

og

Medisinsk avdeling

Sørlandet sykehus Kristiansand

\section{Mette Kalager}

Avdeling for helseledelse og helseøkonomi Universitetet i Oslo

og

Avdeling for transplantasjonsmedisin og K.G Jebsen senter for kolorektal cancer

Oslo universitetssykehus

\section{Michael Bretthauer}

Avdeling for helseledelse og helseøkonomi Universitetet i Oslo

og

Avdeling for transplantasjonsmedisin

og K.G. Jebsen senter for kolorektal cancer

Oslo universitetssykehus

og

Sørlandet sykehus

Alle forfatterne er tilknyttet K.G. Jebsen senter for kolorektal cancer.

e-fig 1 finnes i Tidsskriftets elektroniske utgaver

> Se lederartikkel side 1059

Tit

Engelsk oversettelse på www.tidsskriftet.no 


\section{HOVEDBUDSKAP}

Økonomiske incentiver påvirket ikke deltagelsen i denne spørreskjemaundersøkelsen om risikofaktorer for kolorektal kreft

Resultatet var uavhengig av tidligere invitasjon til koloskopiscreening og om incentivet var betinget av deltagelse

Det bør utredes hvor mye telefonpurring og telefonintervju øker deltagelsen i medisinske og helsefaglige studier pen, som innebar invitasjon til koloskopi, eller kontrollgruppen, som ikke ble tilbudt koloskopi.

Koloskopiene ble gjennomført ved Sørlandet sykehus ved avdelingene i Arendal og Kristiansand mellom januar 2011 og juni 2014. Av de inviterte møtte 5354 (61\%) til screeningundersøkelsen og fikk gjort koloskopi.

\section{Spørreskjemaet}

Alle som møtte til koloskopiscreening Arendal og Kristiansand fylte ved fremmøte ut et validert spørreskjema om livsstil og risikofaktorer for kolorektal kreft $(24,25)$. Skjemaet var på én side og inneholdt fire domener: høyde og vekt, selvrapporterte diagnoser, røyking og familieanamnese for kolorektal kreft. Vi brukte samme skjema i spørreskjemastudien vår (e-fig 1).

\section{Utsending og innsamling av data}

I september 2014 sendte vi spørreskjemaet til et utvalg av personer som var inkludert $\mathrm{i}$ NordICC-studien, men som ikke hadde gjennomgått koloskopiscreening. Det var alle som var randomisert til koloskopi, men som ikke hadde møtt til undersøkelsen (enten fordi de hadde sagt nei, ikke kunne delta eller ikke hadde svart på invitasjonen) og et tilfeldig utvalg av personer fra kontrollgruppen (ikke invitert til koloskopi). I denne artikkelen kalles den første gruppen «screeninginviterte» og den andre «kontrollgruppen» (fig 2).

Skjemaet ble sendt i posten til alle inkluderte i spørreskjemastudien (rødt i fig 2). Konvolutten inneholdt informasjons- og samtykkebrev, spørreskjemaet og frankert svarkonvolutt. Ordlyden i informasjonsbrevet var tilpasset studiearmene. Brevet inneholdt også informasjon om hvordan man kunne besvare skjemaet på internett (webskjema utarbeidet av Epinion).

De som ikke returnerte spørreskjemaet innen tre uker etter utsendelse, ble kontaktet via telefon og spurt om de ønsket å delta $\mathrm{i}$ studien. De ble gitt ulike alternativer for besvarelse. Dersom de fortsatt hadde skjemaet hjemme, kunne de fylle det ut og returnere det, de kunne få en lenke til et webskjema på SMS eller e-post eller de kunne besvare spørsmålene direkte på telefon til vedkommende som ringte eller bli ringt tilbake på et mer egnet tidspunkt. Oppring-

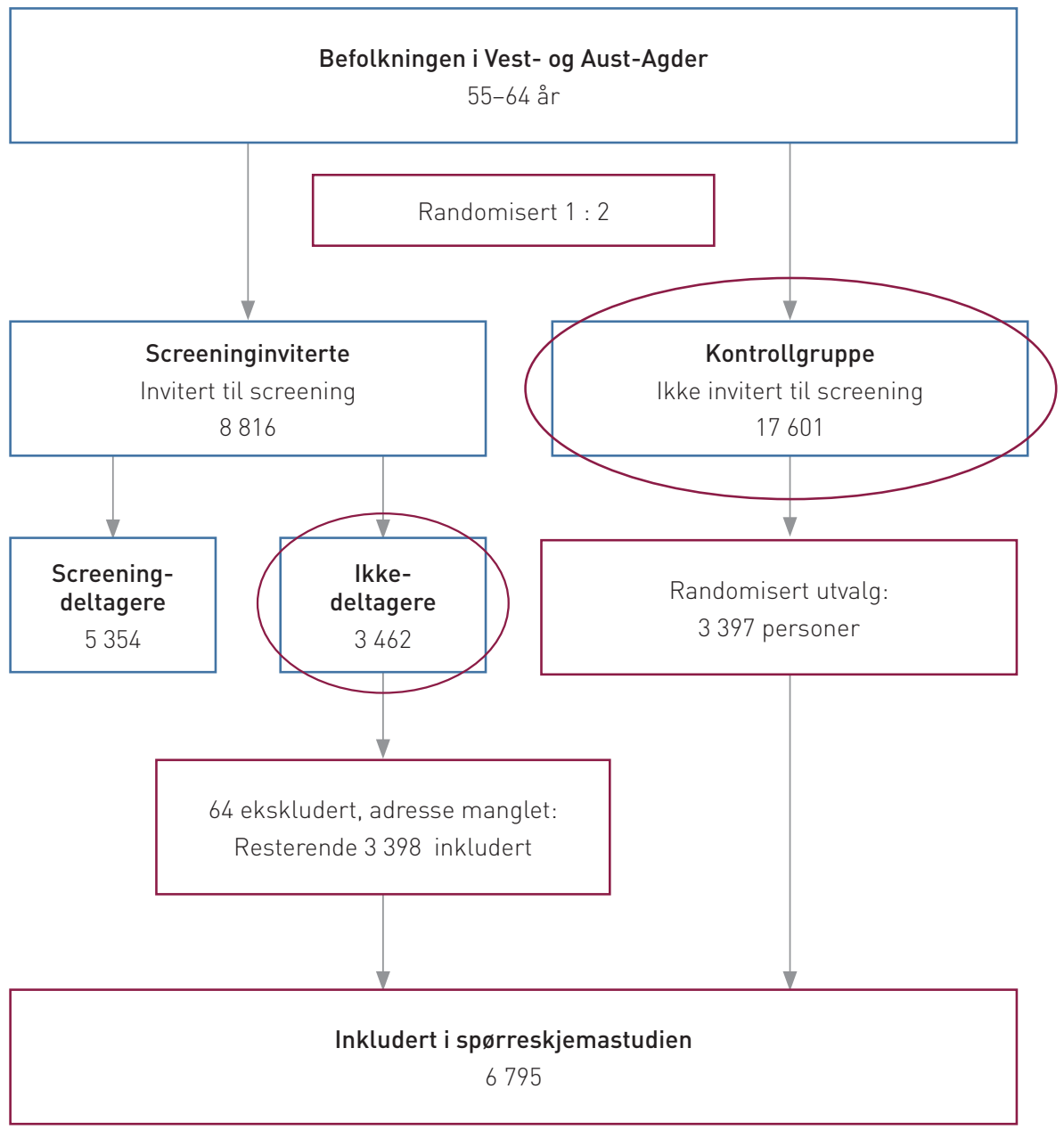

Figur 2 Flytdiagram for NordICC-studien i Norge og utvalget som er inkludert i spørreskjemastudien (i rødt) 


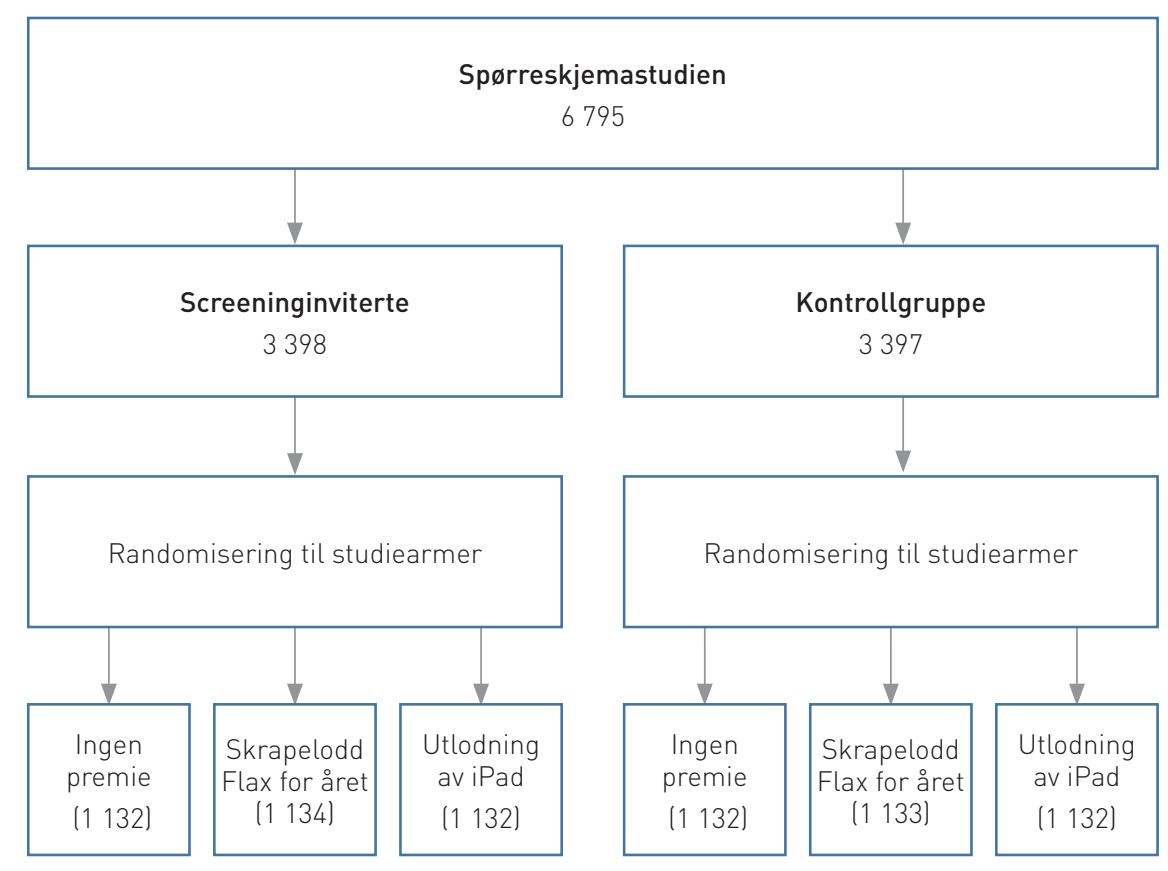

1. runde: Informasjonsbrev med spørreskjema på papir og alternativ om å svare via webskjema sendt i posten

2. runde: Påminnelse ved telefonoppringning til dem som ikke har svart etter 3 uker med mulighet for å besvare skjemaet i telefonintervju

Figur 3 Studiens design

ning og eventuelt telefonintervju ble gjennomført av Epinion etter manus utarbeidet i samarbeid mellom forskerne og prosjektleder i Epinion.

\section{Randomisering til ulike incentiver}

Hver av de to studiegruppene (screeninginviterte og kontrollgruppen) ble før utsending av brevet randomisert $(1: 1: 1)$ til tre ulike studiearmer (fig 3). Den første gruppen fikk intet incentiv. Den andre gruppen fikk et ubetinget insentiv, et tikroners «Flax for Året»-skrapelodd fra Norsk Tipping i brevet. Den tredje gruppen fikk et betinget incentiv dersom de svarte, var de med på trekningen av fire nettbrett (iPad). Deltagerne i alle de tre armene ble motivert til å svare ved setningen «Ditt svar vil gi verdifull informasjon om hvordan forekomst av tarmkreft henger sammen med ulike risikofaktorer».

Det var således to faktorer som kunne påvirke svarprosenten. Den første av disse var studiegruppe (screeninginviterte eller kontrollgruppe). De screeninginviterte hadde tidligere fått tilbud om koloskopi, men hadde valgt ikke å akseptere tilbudet. Deltagerne i kontrollgruppen var et tilfeldig utvalg av den generelle befolkningen i denne aldersgruppen. Siden de screeninginviterte besto av personer som hadde valgt å la være å møte til screening, kunne man her forvente en lavere svarprosent enn i den generelle befolkningen (her representert ved kontrollgruppen) $(1,25)$. Den andre faktoren som kunne påvirke svarprosenten var incentivarmen. I alt besto derfor studien av seks ulike grupper (fig 3) - tre studiearmer med ulike incentiver for henholdsvis screeninginviterte og kontrollgruppen.

\section{Statistikk og styrkeberegning}

Ut fra tidligere erfaringer med utsending av spørreskjema om livsstil og kolorektal kreft til tilsvarende studiegrupper antok vi at $10 \%$ av de screeninginviterte og $60 \%$ i kontrollgruppen ville besvare spørreundersøkelsen uten incentiver $(24,25)$, altså en samlet deltagelse på 35\%. Med 7000 inkluderte hadde studien $>90 \%$ statistisk styrke (med tosidig alfa på 0,05 ) til å påvise en forskjell i deltagelse mellom ikke-incentivarmen og incentivarmene på $10 \%$ og $>80 \%$ styrke til å påvise en forskjell på $7 \%$.

Statistisk signifikans ble testet med Fishers eksakte test, khikvadrattest eller t-test, avhengig av type data. Vi beregnet relativ risiko for forskjellene i svarprosent mellom randomiseringsarmene. Breslow-Day-testen for homogenitet ble brukt for å finne forskjeller mellom screening- og kontrollgruppen for de ulike incentivene. Analysene ble gjort med SAS versjon 9.2 for Windows (26).

\section{Etikk}

Studien er godkjent av regional komité for medisinsk og helsefaglig forskningsetikk. NordICC-studien er registrert i clinicaltrials.gov (NCT00883792). Besvaring av spørreskjemaet (på papir, internett eller telefon) ble ansett som samtykke til deltagelse.

\section{Resultater}

Vi sendte ut 6795 spørreskjemaer - 3398 til ikke-deltagere av de screeninginviterte og 3397 til personer i kontrollgruppen. Det var ingen statistisk signifikante forskjeller i alder, kjønn eller sykehustilhørighet mellom dem som var invitert til screening og kontrollgruppen (tab 1).

Etter purring hadde 3705 av 6795 inkluderte besvart spørreundersøkelsen $(54,5 \%)$ 2817 (76,0\% av respondentene) sendte tilbake det utfylte spørreskjemaet i posten, 537 $(14,5 \%)$ svarte over telefon og $351(9,5 \%)$ besvarte skjemaet på internett. Av de screeninginviterte var det 1478 personer som svarte $(43,5 \%)$, sammenlignet med 2227 $(65,6 \%)$ i kontrollgruppen $(\mathrm{p}<0,001)$. Det kom 54 brev i retur fra posten. Av disse ble de med kjent telefonnummer ringt i purrerunden og kunne svare via telefonintervju eller få link til webskjema på e-post eller SMS.

\section{Effekt av incentiver}

I den incentivarmen som var randomisert til ingen premie, svarte 1223 personer $(54,0 \%)$, i skrapeloddarmen svarte $1214(53,6 \%)$ og i utlodningsarmen svarte $1268 \quad(55,9 \%)$. Figur 4 viser svarmønsteret for de ulike incentivarmene hos personer i screeninginvitert- og kontrollgruppen.

Det var ingen signifikante forskjeller $\mathrm{i}$ svarprosent mellom de ulike incentivene totalt sett $(p=0,24)$, heller ikke innenfor kontrollgruppen $(p=0,67)$ eller de screeninginviterte $(\mathrm{p}=0,29)$.

\section{Effekt av purring og svarmetode}

Før purring svarte 2664 personer $(39,2 \%)$, mens ytterliggere $1041(15,3 \%)$ svarte etter telefonpurring. Andelen som svarte var høyere i kontrollgruppen både før og etter purring (fig 4), og den totale effekten av purring var høyere $\mathrm{i}$ kontrollgruppen enn for de screeninginviterte (henholdsvis $16,5 \%$ og $14,1 \%$ svarte etter purring; $p<0,001)$. Andelen svar avgitt i telefonintervju var 19,9\% (294 personer) blant de screeninginviterte og 10,9\% (243 personer) i kontrollgruppen $(\mathrm{p}<0,001)$.

I alt 817 personer (12\%) ble ikke purret, primært fordi det manglet informasjon om 
Tabell 1 Deltagerkarakteristika og resultat fordelt på studiegrupper

\begin{tabular}{|c|c|c|c|c|c|c|}
\hline & \multicolumn{2}{|c|}{$\begin{array}{l}\text { Screeninginviterte } \\
\qquad N=3398\end{array}$} & \multicolumn{2}{|c|}{$\begin{array}{l}\text { Kontrollgruppe } \\
\qquad \mathrm{N}=3397\end{array}$} & \multicolumn{2}{|c|}{$\begin{array}{c}\text { Totalt } \\
N=6795\end{array}$} \\
\hline & Antall & $(\%)$ & Antall & $(\%)$ & Antall & $(\%)$ \\
\hline Svarte på spørreskjema & 1478 & $(43,5)$ & 2227 & $(65,6)$ & 3705 & $(54,5)$ \\
\hline \multicolumn{7}{|l|}{ Kjønn } \\
\hline Kvinne & 790 & $(53,4)$ & 1173 & $(52,7)$ & 1963 & $(53,0)$ \\
\hline Mann & 688 & $(46,6)$ & 1054 & $(47,3)$ & 1742 & $(47,0)$ \\
\hline Alder (år) (gjennomsnitt, standardavvik) & 62,0 & $(3,0)$ & 61,9 & $(3,0)$ & & \\
\hline \multicolumn{7}{|l|}{ Screeningsenter } \\
\hline Arendal & 627 & $(42,4)$ & 927 & $(41,6)$ & 1554 & $(41,9)$ \\
\hline Kristiansand & 851 & $(57,6)$ & 1300 & $(58,4)$ & 2151 & $(58,1)$ \\
\hline Svarte før purring & 999 & $(29,4)$ & 1665 & (49) & 2664 & $(39,2)$ \\
\hline Svarte etter purring & 479 & $(14,1)$ & 562 & $(16,5)$ & 1041 & $(15,3)$ \\
\hline $\begin{array}{l}\text { Svarte via telefonintervju (prosent oppgitt som andel telefonsvar } \\
\text { av alle svar) }\end{array}$ & 294 & $(19,9)$ & 243 & $(10,9)$ & 537 & $(14,5)$ \\
\hline Svarte ikke & 1920 & $(56,6)$ & 1170 & $(34,5)$ & 3090 & $(45,5)$ \\
\hline $\begin{array}{l}\text { Av disse: Ikke purret (manglet telefonnummer eller ble av andre } \\
\text { praktiske årsaker ikke kontaktet av Epinion) }\end{array}$ & 509 & $(15,0)$ & 308 & $(9,1)$ & 817 & $(12,0)$ \\
\hline
\end{tabular}

telefonnummer $(15 \%$ av de screeninginviterte, mot $9 \%$ i kontrollgruppen; $\mathrm{p}<0,001)$.

\section{Diskusjon}

Resultatene fra vår studie viser at bruk av økonomiske incentiver som mindre gaver (skrapelodd) eller utlodning av større gaver (nettbrett) ikke ga økt deltagelse i en medisinsk spørreundersøkelse utført $i$ aldersgruppen 55-64 år.

Deltagelsen var 54,5\%. Det er lavere enn det som er rapportert fra tilsvarende undersøkelser i Norge tidligere $(1,6,7,27)$. Våre resultater viser at de som har avstått fra å delta i koloskopiscreening (screeninginviterte), hadde lavere svarprosent enn kontrollgruppen. Andelen av de screeninginviterte som svarte $(43,5 \%)$ var likevel betydelig høyere enn de $11 \%$ som ble observert $i$ en lignende gruppe av ikke-møtte i en tilsvarende spørreskjemastudie om risikofaktorer for kolorektal kreft i 2006 (25). Den høyere deltagelsen blant ikke-møtte i vår studie var overraskende, da omfang og tema for undersøkelsen var nokså likt det den tidligere undersøkelsen. Mulige forklaringer kan være at vår målgruppe besto av personer som var mellom fem og ti år eldre enn i den tidligere studien, at skjemaet vårt inneholdt færre spørsmål og at vi purret dem som ikke hadde svart.

Hensikten med spørreundersøkelser er å

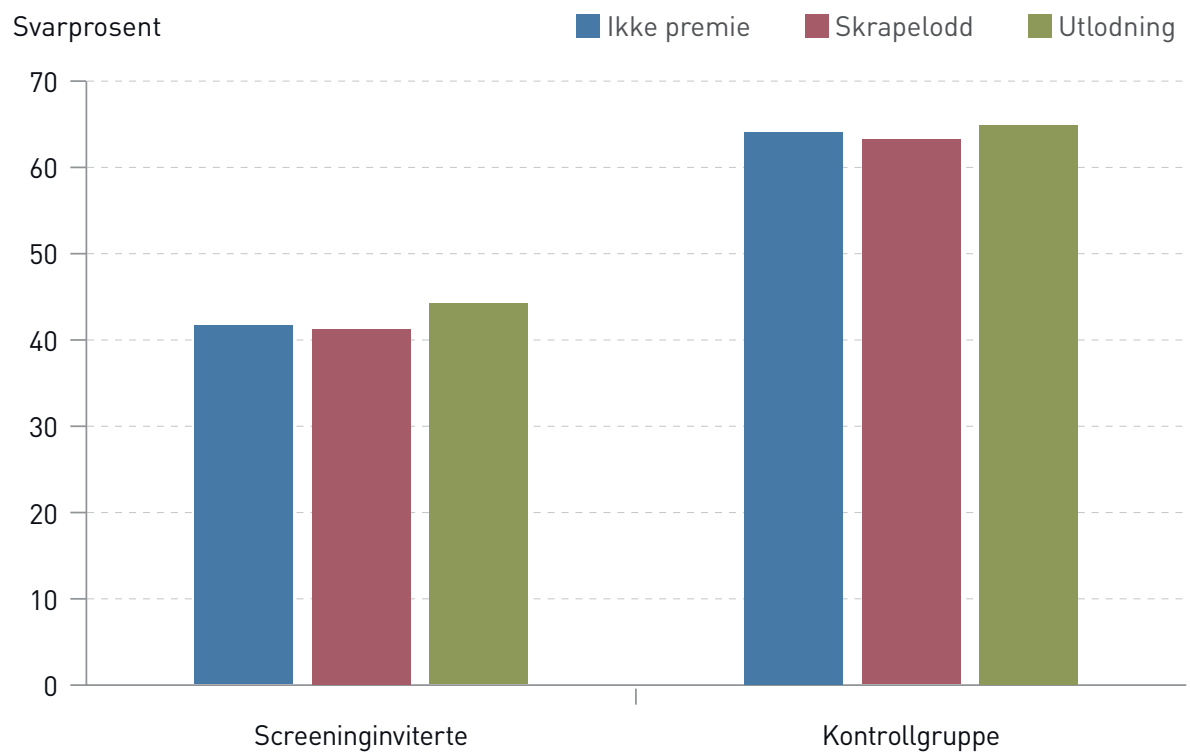

Figur 4 Andel som svarte på spørreskjemaundersøkelsen fordelt på screeninginviterte og kontrollgruppe og etter ulike incentiver 
fremskaffe innsikt som ikke bare er gyldig for dem som har svart, men for en større gruppe mennesker. Dermed ønsker man at gruppen som svarer er så «lik» den større gruppen som mulig, altså at de utgjør et representativt utvalg. Som undersøker kan man kontrollere at de som inviteres til å delta $i$ en spørreundersøkelse er representative ved å gjøre et tilfeldig utvalg. Men man kan ikke kontrollere at de som faktisk besvarer undersøkelsen er representative.

Høy svarprosent kan være en indikasjon på et mer representativt utvalg, men det er ingen garanti for at dette er riktig. Det kan fremdeles være personer med spesielle karakteristika som i liten grad er villig til å besvare undersøkelsen, og dette kan medføre måleskjevheter sammenlignet med om alle hadde svart. For eksempel er personer med lav sosioøkonomisk status og høy forekomst av livsstilsrelaterte sykdommer ofte underrepresentert $(1,2)$, hvilket gir kunstig lave forekomsttall for mange sykdommer. Slike skjevheter er mer tydelige ved måling av forekomst av en tilstand enn ved måling av sammenhenger mellom eksponering og et utfall (28).

I en Cochrane-oversikt om bruk av incentiver i spørreskjemaundersøkelser (ikke bare medisinske) var det større effekt av ubetingede incentiver som kunne brukes av deltagerne uavhengig om de svarte eller ikke (som med skrapeloddet i vår studie) enn av betingede incentiver som ble utlevert når spørreskjemaet var besvart (10). Våre resultater viste ingen signifikant effekt av det ubetingede incentivet (tikronersskrapeloddet). Det stemmer godt med resultatene fra en norsk studie fra 2006, der man ikke fant økt svarprosent etter utdeling av skrapelodd (22). I en annen norsk studie fra 2012 ble det imidlertid konkludert motsatt: Det å legge ved et skrapelodd ga $10 \%$ høyere svarprosent enn ingen premie (21).

Tilbakemeldingene fra de som utførte purringene og telefonintervjuene var at mange deltagere var høyt motivert til å svare. Mange uttrykte at tarmkreft var et tema de var opptatt av og syntes det var viktig å forske på. Vi har dermed indikasjoner på at deltagerne $i$ vår studie i utgangspunktet var relativt høyt indre motivert for å svare. Dette kan ha bidratt til mangelen på effekt av de ytre økonomiske incentivene. Andre faktorer som kan ha bidratt til mangel på effekt av incentivene er at studien ble utført i en aldersgruppe vi kan anta er mer bemidlede enn unge mennesker, de har råd til å kjøpe nettbrett og skrapelodd selv. Spørreskjemaet var dessuten relativt kort - vi kan anta at det krever mindre ytre motivasjon enn et langt, tidkrevende skjema.

Mer enn $40 \%$ av de screeninginviterte valgte å svare på spørreskjemaet på tross av at de hadde avslått screeningundersøkelse med koloskopi. Vår forventning var at det skulle være stor samvariasjon mellom det å avstå fra screening og det å avstå fra å besvare spørreskjemaet. At denne samvariasjonen var mindre enn forventet, kan tyde på at seleksjonsmekanismene er ulike. Det kan være helsemessige eller praktiske grunner til at man ikke fikk gjort koloskopiscreening, for eksempel jobb eller vanskeligheter med transport, men at man likevel besvarte et spørreskjema som bare tok noen minutter og kunne gjøres hjemme. Det kan også være frykt for at koloskopi skal være en ubehagelig opplevelse, mens denne mekanismen ikke spiller inn for spørreskjemaundersøkelsen.

$\mathrm{Vi}$ fant ingen økt svarandel ved å yte incentiver til deltagerne $\mathrm{i}$ denne medisinske spørreskjemaundersøkelsen - verken incentiver som betinget deltagelse eller ubetingede incentiver hadde effekt. Derimot observerte vi en vesentlig effekt av telefonpurring av deltagere som ikke hadde svart, med mulighet for å besvare undersøkelsen over telefon. Denne økningen i svarandel var særlig uttalt blant de screeninginviterte, en gruppe som er vanskelig å nå med slike helseundersøkelser.

Hvorvidt telefonpurring er mer effektivt enn postal purring, og hvorvidt alternative besvarelsesmetoder i seg selv øker deltakelsen, må imidlertid undersøkes nærmere, sammen med eventuelle metodiske, økonomiske og etiske aspekter ved ulike alternativer. Ved planlegging av nye studier i tilsvarende befolkningsgrupper kan det imidlertid være hensiktsmessig å prioritere ressurser til purring og alternative svarformer fremfor å tilby incentiver.

Prosjektet ble støttet ved tildelinger fra Helse SørØst, Norges forskningsråd og Kreftforeningen.

\section{Dagrun Kyte Gjøstein (f. 1986)}

er sosialantropolog og doktorgradsstipendiat ved klinisk effekt-forskningsgruppen ved Universitetet i Oslo/Oslo universitetssykehus Forfatter har fylt ut ICMJE-skjemaet og oppgir ingen interessekonflikter.

\section{Anders Huitfeldt (f. 1982)}

er lege og var doktorgradsstipendiat ved program for kausal inferens ved Harvard TH Chan School of Public Health og forsker ved klinisk effekt-forskningsgruppen ved Universitetet i Oslo/Oslo universitetssykehus. Han er postdoktor ved Stanford University School of Medicine.

Forfatter har fylt ut ICMJE-skjemaet og oppgir ingen interessekonflikter.

\section{Magnus Løberg (f. 1979)}

er lege og postdoktor ved klinisk effekt-forskningsgruppen ved Universitetet i Oslo/Oslo universitetssykehus.

Forfatter har fylt ut ICMJE-skjemaet og oppgir ingen interessekonflikter.

\section{Hans-Olov Adami (f. 1942)}

er professor og tidligere leder ved Department of Epidemiology, Harvard TH Chan School of Public Health. Han er professor emeritus, var instituttleder ved Institutionen för medicinsk epidemiologi och biostatistik, Karolinska institutet, og er forsker ved klinisk effekt-forskningsgruppen ved Universitetet i Oslo/Oslo universitetssykehus.

Forfatter har fylt ut ICMJE-skjemaet og oppgir ingen interessekonflikter.

\section{Kjetil Garborg (f. 1976)}

er lege i spesialisering i fordøyelsessykdommer ved Gastromedisinsk seksjon, Avdeling for transplantasjonsmedisin, Oslo universitetssykehus, og medlem i klinisk effekt-forskningsgruppen ved Universitetet i Oslo/Oslo universitetssykehus.

Forfatter har fylt ut ICMJE-skjemaet og oppgir ingen interessekonflikter.

\section{Mette Kalager (f. 1967)}

er lege og førsteamanuensis ved Universitetet i Oslo og forsker ved Avdeling for transplantasjonsmedisin, Oslo universitetssykehus. Hun leder klinisk effekt-forskningsgruppen ved Universitetet i Oslo/Oslo universitetssykehus. Forfatter har fylt ut ICMJE-skjemaet og oppgir ingen interessekonflikter.

\section{Michael Bretthauer (f. 1969)}

er professor ved Universitetet i Oslo og overlege ved Gastromedisinsk seksjon, Avdeling for transplantasjonsmedisin, Oslo universitetssykehus. Han er forsker ved klinisk effektforskningsgruppen ved Universitetet i Oslo/ Oslo universitetssykehus.

Forfatter har fylt ut ICMJE-skjemaet og oppgir ingen interessekonflikter.

\section{Litteratur}

1. Amundsen B. Folk svarer ikke lenger. Bladet Forskning 2013. www.forskningsradet.no/ bladetforskning/Nyheter/Folk svarer ikke lenger/1253986892964 (8.10.2015).

2. Langhammer A, Krokstad S, Romundstad P et al. The HUNT study: participation is associated with survival and depends on socioeconomic status, diseases and symptoms. BMC Med Res Methodol 2012; 12: 143

3. Lagergren J, Bergström R, Lindgren A et al. Symptomatic gastroesophageal reflux as a risk factor for esophageal adenocarcinoma. N Engl J Med 1999; 340: 825-31.

4. Smedby KE, Hjalgrim H, Melbye M et al. Ultraviolet radiation exposure and risk of malignant lymphomas. J Natl Cancer Inst 2005; 97: 199-209. 
5. Frisch M, Glimelius B, van den Brule AJC et al Sexually transmitted infection as a cause of anal cancer. N Engl J Med 1997: 337: 1350-8.

6. Krokstad S, Langhammer A, Hveem Ket al. Cohort Profile: the HUNT Study, Norway. Int J Epidemiol 2013; 42: 968-77.

7. Jacobsen BK, Eggen AE, Mathiesen EB et al. Cohort profile: the Tromso Study. Int J Epidemiol 2012; 41: $961-7$

8. Magnus P, Irgens LM, Haug K et al; MoBa Study Group. Cohort profile: the Norwegian Mother and Child Cohort Study (MoBa). Int J Epidemiol 2006: 35: $1146-50$.

9. Galea S, Tracy M. Participation rates in epidemiologic studies. Ann Epidemiol 2007; 17: 643-53.

10. Edwards PJ, Roberts I, Clarke MJ et al. Methods to increase response to postal and electronic questionnaires. Cochrane Database Syst Rev 2009: 3: MR000008.

11. Dillman DA, West KK, Clark JR. Influence of an invitation to answer by telephone on response to census questionnaires. Public Opin Q 1994; 58: 557-68.

12. Dillman DA, Smyth JD, Christian LM. The tailored design method. I: Hoboken NJ, red. Internet, mail, and mixed-mode surveys: the tailored design method. Hoboken, NJ: Wiley, 2009

13. Dillman DA, Phelps G, Tortora R et al. Response rate and measurement differences in mixed-mode surveys using mail, telephone, interactive voice response (IVR) and the Internet. Soc Sci Res 2009; 38: $1-18$.
14. Dillman DA. Why choice of survey mode makes a difference. Public Health Rep 2006: 121: 11-3.

15. Dillman DA. The Design and Administration of Mai Surveys. Annu Rev Sociol 1991; 17: 225-49.

16. Yu J, Cooper H. A Quantitative Review of Research Design Effects on Response Rates to Questionnaires. J Mark Res 1983; 20: 36-44.

17. Eaker S, Bergström R, Bergström A et al. Response rate to mailed epidemiologic questionnaires: a population-based randomized trial of variations in design and mailing routines. Am J Epidemiol 1998; $147: 74-82$

18. Heijmans N, van Lieshout J, Wensing M. Improving participation rates by providing choice of participation mode: two randomized controlled trials. BMC Med Res Methodol 2015; 15: 29

19. Ronckers C. Land C. Hayes R et al. Factors impacting questionnaire response in a Dutch retrospective cohort study. Ann Epidemiol 2004 14: $66-72$.

20. van der Mark LB, van Wonderen KE, Mohrs J et al. The effect of two lottery-style incentives on response rates to postal questionnaires in a prospective cohort study in preschool children at high risk of asthma: a randomized trial. BMC Med Res Methodol 2012: 12: 186.

21. Olsen F, Abelsen B, Olsen JA. Improving response rate and quality of survey data with a scratch lottery ticket incentive. BMC Med Res Methodol 2012 12: 52.

22. Finsen V, Storeheier AH. Scratch lottery tickets are a poor incentive to respond to mailed questionnaires. BMC Med Res Methodol 2006; 6: 19

23. Kaminski MF, Bretthauer M, Zauber AG et al. The NordICC Study: rationale and design of a randomized trial on colonoscopy screening for colorectal cancer. Endoscopy 2012; 44: 695-702.

24. Larsen IK, Grotmol T, Almendingen K et al. Impact of colorectal cancer screening on future lifestyle choices: a three-year randomized controlled trial. Clin Gastroenterol Hepatol 2007; 5: 477-83.

25. Larsen IK, Grotmol T, Almendingen K et al. Lifestyle characteristics among participants in a Norwegian colorectal cancer screening trial. Eur J Cancer Prev 2006; 15: 10-9.

26. SAS Institute Inc. Cary, NC. www.sas.com/no no/ home.html (13.5.2016).

27. Finsen V, Storeheier AH. Scratch lottery tickets are a poor incentive to respond to mailed questionnaires. BMC Med Res Methodol 2006; 6: 19

28. Nilsen RM, Vollset SE, Gjessing HK et al. Selfselection and bias in a large prospective pregnancy cohort in Norway. Paediatr Perinat Epidemiol 2009; 23: 597-608.

Mottatt 15.10. 2015, første revisjon innsendt 19.2. 2016, godkjent 13.5. 2016. Redaktør: Ragnhild Ørstavik. 